\title{
Report of The Research and Survey Committee for Ceramics
}

\author{
Reporter: Noboru Ichinose*
}

\section{Introduction}

The history of light sources is a history of an improvement of lamp efficiency. It was a long way from an incandescent lamp using carbon filament of several $\mathrm{lm} / \mathrm{W}$ invented by Edison 100 years or more ago to a current high intensity discharge lamp of $140-150 \mathrm{~lm} / \mathrm{W}$. However, these studies are closely related to a development of materials, necessarily. During this decade, representative examples can be seen in a development of rare earth fluorescent material in three band fluorescent lamp, a development of translucent alumina in high pressure sodium lamp, a development of multilayered ceramic film in incandescent lamp with infrared reflecting film and so on. Therefore, it can be said that the history of a development of lamp is a history of a development of light source materials.

As mentioned in above, a role fulfiled by fine ceramics as a light source material, especially as a part of high technology, is important in the history of lamp. Now, in this respect, it is important to survey and summarize results already obtained and tasks remained as a future study for a technological development in this field and for the effort towards its practical use.

Based on these viewpoints, the Research and Survey Committee for Ceramic was established in September, 1985 and since then the Committee was held 14 times until February, 1988, wherein the current and future trend of ceramics was studied energetically. This report is a summary thereof.

(Members of the Committee)

Chairman: N. Ichinose

(Waseda University)

Secretary: K. Narita

(Toshiba Co., Ltd.)

K. Nagata
(National Defense Academy)

Member : H. Takahashi

(Matsushita Electric Works, Ltd.)

N. Igarashi

(Toshiba Ceramics Co., Ltd.)

T. Takehara

(Nihon Gaishi Co., Ltd.)

T. Ohmori

(Toshiba Glass Co., Ltd.)

K. Watanabe

(Mitsubishi Denki Co., Ltd.)

M. Sugiura

(Iwasaki Denki Co., Ltd.)

H. Matsuno

(Hitachi Seisakusho Co., Ltd.)

S. Nakajima

(Nichia Kagaku Co., Ltd.)

T. Yamamoto

(Matsushita Electronics Co., Ltd.)

Y. Yokomizo

(Toshiba Co., Ltd.)

\section{Progress Report}

The Committee was held 14 times and in the Committee the proposed current problems were discussed mainly in reference to member's opinion from the standpoint of his specialized field and a hearing from relating specialists. Also, a lecture meeting and a sympsium were held.

\subsection{Lecture Meeting and Symposium}

An educational activity for the members of the Illum. Eng. Inst. of Japan was sponsored by the Committee, in which two lecture meetings and one symposium were held.

\subsubsection{Lecture meeting}

(I) The 1st lecture meeting (Nov. 26, 1986) ${ }^{(2)}$ 
It was held mainly concerning ceramics jointly with the Subcommittee of Survey of Optics Relating Material and Device.

(1) A progress of ceramics for light source

- N. Ichinose (Waseda University)

(2) Translucent zirconia - K. Tsukuma (Toyo Soda Co., Ltd.)

(3) Translucent aluminum nitride

- H. Taniguchi et al (Tokuyama Soda Co., Ltd.)

(4) Far-infrared radiation ceramics

- M. Kawaguchi

(Asahi Glass Co., Ltd.)

(5) Ceramics for infrared reflecting film

- T. Saito et al (Nihon Soda Co., Ltd.)

(6) Ceramics for infrared rays sensor

- S. Ito

(Murata Seisakusho Co., Ltd.)

(7) Color development of ceramics and its property

- J. Ohtsuka

(Yokohama National University)

- T. Takenaga

(Sumitomo Cement Co., Ltd.)

(II) The 2nd lecture meeting (Mar. 9, 1986)

It was held as a meeting for officializing this survey report.

(1) General

(2) Glass

- N. Ichinose (Waseda University)

- T. Ohmori (Toshiba Glass Co., Ltd.)

(3) Ceramics

- K. Narita (Toshiba Co., Ltd.)

(4) Optoelectronic device

- K. Nagata (National Defense Academy)

(5) A desire for ceramics from users

- K. Watabe

(Mitsubishi Denki Co., Ltd.)

- H. Takahast

(Matsushita Electronics Co., Ltd.)

\subsubsection{Symposium (Sept. 11, 1987)}

A symposium titled as "Research trend of light transmissive ceramics" was held in "The 1987 Joint Meeting of Institutes Relating to Electrics and Informations".

(1) Current trend of translucent ceramics

- N. Ichinose (Waseda University)
(2) Translucent alumina

- N. Igarashi

(Toshiba Ceramics Co., Ltd.)

(3) Translucent aluminum nitride

$-\mathrm{H}$. Taniguchi et al (Tokuyama Soda Co., Ltd.)

(4) Translucent yttrium - aluminum - garnet

- H. Hada

(National Institute for Research)

(5) Translucent magnesia

- S. Matsuda

(National Institute for Research in Inorganic Materials)

(6) Translucent zirconia

- K. Tsukuma (Toyo Soda Co., Ltd.)

\section{Present State of Ceramics}

For a light source material, such a variety of materials as metal, organic material and ceramics is used. However, in this report, ceramics which is recently payed attention as a new material is featured and surveyed in relation to illumination, especially light source.

\subsection{Glass}

(a) Glass for illumination

It can be said that it seems that the variety of glass type has a connection with a variety of glass for illumination. That is to say, a history of glass for illumination is "a history of light" so that at each invention of a new light source a glass having a new property was discovered. However, it is a current trend to give a priority to material and power conservation while searching a new material property from a variety of properties. Now, among these glasses for illumination, low-leaded glass and quartz glass for ring type fluorescent lamp will be described in the following.

Concerning a quality improvement of fluorescent lamp, a progress in an upgrading of such a property as initial luminous flux, life performance property, mean life and color lendering property has been almost saturated. Recently, on the other hand, according to social needs, an improvement is being directed mainly to such an economic factor as material and power conservation. However, a competition for property upgrading between fluorescent lamp manufacturers has never been ended. Conversely, a more severe competition including a rationalization of 
Table 1 Comparison of materials of glass for ring type fluorescent lamp

\begin{tabular}{|c|c|c|c|c|c|c|c|c|c|c|}
\hline \multirow[b]{2}{*}{ Glass type } & \multicolumn{6}{|c|}{ Glass composition (wt\%) } & \multirow[b]{2}{*}{$\begin{array}{l}\text { Thermal expan- } \\
\text { sion coefficient } \\
\left(\times 10^{-7} /{ }^{\circ} \mathrm{C}\right)\end{array}$} & \multirow[b]{2}{*}{$\begin{array}{c}\text { Softening } \\
\text { temperature } \\
\left({ }^{\circ} \mathrm{C}\right)\end{array}$} & \multirow[b]{2}{*}{$\begin{array}{l}\text { Density } \\
\left(\mathrm{g} / \mathrm{cm}^{3}\right)\end{array}$} & \multirow{2}{*}{$\begin{array}{l}\text { Chemical } \\
\text { resistance } \\
\text { (Daikohshi } \\
\text { method } \\
\text { (ml) }\end{array}$} \\
\hline & $\mathrm{SiO}_{2}$ & $\mathrm{Na}_{2} \mathrm{O}$ & $\mathrm{K}_{2} \mathrm{O}$ & $\mathrm{PbO}$ & $\mathrm{CaO}$ & $\mathrm{MgO}$ & & & & \\
\hline Low-leaded glass & 68 & 15.7 & 1.0 & 5.5 & 5.6 & 2.5 & 100 & 680 & 2.59 & 6.1 \\
\hline A glass & 71 & 16.0 & 1.5 & - & 6.0 & 2.8 & 98 & 700 & 2.45 & 8.5 \\
\hline $\mathrm{B}$ glass & 58 & 5.0 & 6.8 & 28.0 & - & - & 95 & 618 & 3.03 & 3.4 \\
\hline $\mathrm{C}$ glass & 61 & 9.8 & 3.6 & 23.5 & 0.5 & - & 97 & 618 & 2.93 & 9.2 \\
\hline
\end{tabular}

* Glass Engineering Handbook (1972) (Japan)

production line is under progress. In particular, low-leading of glass for ring type fluorescent lamp is payed attention as a factor contributing to a cost-down of a glass bulb cost which occupies a greater part of the lamp cost composition. Table 1 shows a comparison of materials of glass for ring type fluorescent lamp.

Quartz glass is a single oxide glass which is produced by melting pure silicon dioxide $\left(\mathrm{SiO}_{2}\right)$ so that it has features as listed below.

(1) Its purity is very high. It is opaque at about $99.9 \%$ but it becomes transparent at $99.9 \%$ or more.

(2) It has an excellent heat resistance. It does not present any deformation up to $1,100^{\circ} \mathrm{C}$ and is available even at about $1,300^{\circ} \mathrm{C}$. It has a remarkably low thermal expansion coefficient such as $5 \times 10^{-7} /{ }^{\circ} \mathrm{C}$.

(3) It is stable chemically. It can not be attacked by any acid except hydrofluoric acid and phosphoric acid even at high temperature and high concentration.

(4) It has an excellent electrically insulating property. Its specific resistance is about $10^{18} \Omega$-cm.

(5) It has an excellent translucent property. It can transmit a light of $0.2-3.5 \mu \mathrm{m}$.

By utilizing the above-mentioned features, the quartz glass has a variety of applications, e.g. a) prism, lens and cell for spectrophotometer which utilize a light transmissive property in a wide band range, b) various types of window plate having heat resistance and chemical resistance and c) light emitting tube such as mercury arc lamp, metal halide lamp, xenon lamp, tungsten halogen lamp, infrared lamp and germicidal lamp.

(b) New glass

New glass is termed as a glass modified so as to show a specific function of material and form at maximum extent so that it can be said that it takes an important role in the high technology. Concerning material, it consists of glass and amorphous substance (except representative element-semiconductor, metal, carbon and organic polymer), of glass or amorphous substance post-treated (e.g. crystallization, ion exchange and surface treatment) or of a composite material with a matrix of glass or amorphous substance.

A representative new glass includes, for example, optical fiber, optical IC, distributed index lens, glass for optical memory, electrically conductive glass, inorganic photoresist, glass for optical control device, nitride glass, chalcogenide glass, fluoride glass, uniaxially crystallized glass, porous glass, artificial tooth of glass and artificial bone. Table 2 shows functional classification and application example of new glass.

\subsection{Ceramics}

(a) Fluorescent substance

A spectrum which stimulates the fluorescent substance of fluorescent lamp is mainly the $\mathrm{Hg}$ resonance line of $254 \mathrm{~nm}$. Therefore, it is the primary necessary condition for the fluorescent substance of fluorescent lamp to be capable of absorbing sufficiently and converting it into a visible light emission effectively. Furthermore, a light emission by the resonance line of $185 \mathrm{~nm}$ with a strength equal to about $10 \%$ of that of $254 \mathrm{~nm}$ line is not negligible. The smaller the lamp diameter, as seen in the recent trend, the larger the strength ratio between $185 \mathrm{~nm}$ line and $254 \mathrm{~nm}$ line so that the light emitting efficiency controls greatly the performance of fluorescent substance. In a high pressure mercury lamp, approximately one third of total 
Table 2 Functional classification and application example of new glass

\begin{tabular}{|c|c|c|c|c|}
\hline $\begin{array}{l}\text { Functional } \\
\text { field }\end{array}$ & Function & Glass $\cdot$ Crystal glass & $\begin{array}{c}\text { Basic composition } \\
\text { example }\end{array}$ & Application example \\
\hline Optics & $\begin{array}{l}\text { Optical fiber } \\
\text { Optical transmissivity } \\
\text { Laser oscillating property } \\
\text { Photosensitivity } \\
\text { Optical memory } \\
\text { Form stability }\end{array}$ & $\begin{array}{l}\text { Optical fiber } \\
\text { Glass laser } \\
\text { Photo chromic glass } \\
\text { Amorphous oxide } \\
\text { Photo mask }\end{array}$ & $\begin{array}{l}\mathrm{SiO}_{2} \\
\text { Phosphate, Fluophosphate } \\
\mathrm{Na}_{2} \mathrm{O}-\mathrm{Al}_{2} \mathrm{O}_{3}-\mathrm{B}_{2} \mathrm{O}-3-\mathrm{SiO}_{2} \\
\quad(\mathrm{Ag}, \mathrm{Cl}, \mathrm{Br}) \\
\mathrm{Te}-\mathrm{O} \\
\mathrm{SiO} \\
2\end{array}$ & $\begin{array}{l}\text { Optical communication, } \\
\text { microoptics } \\
\text { Nuclear fusion } \\
\text { Variable transmittance } \\
\text { glass } \\
\text { Laser disc } \\
\text { Photo mask }\end{array}$ \\
\hline $\begin{array}{l}\text { Electrical } \\
\text { device }\end{array}$ & $\begin{array}{l}\text { Ion transmissivity } \\
\text { Sound wave transmissivity }\end{array}$ & $\begin{array}{l}\text { High ion transmissive glass } \\
\text { Retarding line glass }\end{array}$ & $\begin{array}{l}\mathrm{AgI}-\mathrm{Ag}_{2} \mathrm{O}-\mathrm{P}_{2} \mathrm{O}_{5} \\
\mathrm{R}_{2} \mathrm{O}-\mathrm{PbO}-\mathrm{SiO}_{2} \\
\text { (R: Alkali) }\end{array}$ & $\begin{array}{l}\text { Battery } \\
\text { Retarding line }\end{array}$ \\
\hline Heat & Thermal stability & $\begin{array}{l}\text { Low expansion glass } \\
\text { Low expansion crystal } \\
\text { glass }\end{array}$ & $\begin{array}{l}\mathrm{TiO}_{2}-\mathrm{SiO}_{2} \\
\mathrm{Li}_{2}-\mathrm{O}-\mathrm{Al}_{2} \mathrm{O}_{3}-\mathrm{SiO}_{2} \\
\left(\mathrm{ZrO}--\mathrm{TiO}_{2}\right)\end{array}$ & $\begin{array}{l}\text { Celestial telescope } \\
\text { Heat exchanger }\end{array}$ \\
\hline Machine & $\begin{array}{l}\text { Alkali resistance } \\
\text { High Young modulus } \\
\text { Workability } \\
\text { High strength } \\
\text { Carrier property }\end{array}$ & $\begin{array}{l}\text { Alkali resisting glass } \\
\text { Oxynitride light glass } \\
\text { Mica crystal glass } \\
\text { Composite crystal glass } \\
\text { Porous glass }\end{array}$ & $\begin{array}{l}\mathrm{Na}_{2} \mathrm{O}-\mathrm{ZrO}{ }_{2}-\mathrm{SiO}_{2} \\
\mathrm{Mg}-\mathrm{Al}-\mathrm{Si}-\mathrm{O}-\mathrm{N} \\
\mathrm{K}_{2} \mathrm{O}-\mathrm{MgO}-\mathrm{Al}_{2} \mathrm{O}_{3}-\mathrm{SiO}_{2}-\mathrm{F} \\
\mathrm{SiC}-\beta \text {-Spodumen } \\
\mathrm{SiO}_{2}\end{array}$ & $\begin{array}{l}\text { Cement reinforcement } \\
\text { Plastic reinforcement } \\
\text { Electrical insula iing } \\
\text { material } \\
\text { High temperature machine } \\
\text { structural material } \\
\text { Fixation enzyme, Heat } \\
\text { extension }\end{array}$ \\
\hline Chemistry & Melting solidifying property & Borosilicate glass & Borosilicate & $\begin{array}{l}\text { Fixation enzyme, Heat } \\
\text { liquid fixation }\end{array}$ \\
\hline $\begin{array}{l}\text { Living } \\
\text { organism }\end{array}$ & Organism compatibility & Apatite crystal glass & $\begin{array}{l}\mathrm{K}_{2} \mathrm{O}-\mathrm{Na}_{2} \mathrm{O}-\mathrm{MgO}-\mathrm{CaO} \\
-\mathrm{P}_{2} \mathrm{O}_{5}-\mathrm{SiO}_{2}\end{array}$ & $\begin{array}{l}\text { Architectural bone, } \\
\text { Architecture }\end{array}$ \\
\hline
\end{tabular}

energy is emitted at the band of 254,313 and $365 \mathrm{~nm}$, respectively. Table 3 shows a list of fluorescent substance for practically used lamps.

(b) Electron emitting material

According to a recent increased demand for high density electron beam, an interest is directed in a great extent to an electron emitting material. As an electron emission from a solid surface, thermal electron emission, electrical field electron emission, secondary electron emission etc. are known.

For fluorescent lamp, an electron emitting material comprising a base material of oxide of $\mathrm{Ba}, \mathrm{Sr}, \mathrm{Ca}$ with a content of $1-10 \%$ of $\mathrm{ZrO}_{2}$ is used. For discharge lamp, $\mathrm{BaO}-\mathrm{CaO}-\mathrm{ThO}_{2}$ system, $\mathrm{Ba}_{2} \mathrm{CaWO}_{6}, \mathrm{Ba}_{1.8} \mathrm{Sr}_{0.2} \mathrm{CaWO}_{6}-\mathrm{Y}_{2} \mathrm{O}_{3}$ $\mathrm{BeO}$ system, $\mathrm{Ba}_{3} \mathrm{Y}_{2} \mathrm{WO}_{9}$ etc. are known.

(c) Translucent ceramics

As represented by chinaware, ceramics is a polycrystal body obtained by sintering raw material powder, which fine structure is generally composed of crystal grain, grain boundary as well as pore. The refractive index of crystal grain is usually larger than $n=1$ (refractive index of air) so that a incident beam to ceramics is scattered at crystal boundary, resulting in an inadvantageous light transmissive property. There fore, ceramics has been thought to be inappropriate for optical material due to its opaqueness. However, since an invention of translucent alumina $\left(\mathrm{Al}_{2} \mathrm{O}_{3}\right)$, a number of light transmissive ceramics including $\mathrm{MgO}, \mathrm{Y}_{2} \mathrm{O}_{3}, \quad \mathrm{ZrO}_{2}$ has appeared successively. Recently, nonoxide ceramics such as AIN or AlON with translucent property was introduced. Typical translucent ceramics are shown in Table 4. Among them, the material ranging from $\mathrm{Al}_{2} \mathrm{O}_{3}$ to $\mathrm{MgO} \cdot \mathrm{Al}_{2} \mathrm{O}_{3}$ has a melting point of $2,000^{\circ} \mathrm{C}$ or more and is superior in heat resistance and strength than glass so that it can be used in a light emitting tube of high pressure discharge mercury lamp or à transparent container.

Recently, a piezoelectric ceramics called as PLZT composed of $\mathrm{PbTiO}_{3}-\mathrm{PbZrO}_{3}$ system with an added $\mathrm{La}_{2} \mathrm{O}_{3}$ became the topic of conversation. This ceramics shows an excellent optoelectrical effect so that its application as a new optical material for information processing, 
Table 3 Typical fluorescent materials for lamp

\begin{tabular}{|c|c|c|c|c|}
\hline \multicolumn{2}{|c|}{ Activating agent } & Material & $\begin{array}{l}\text { Light emitting peak (nm) } \\
\text { and light emissivity }\end{array}$ & Application \\
\hline \multicolumn{2}{|c|}{ Self-activation } & $\begin{array}{l}\mathrm{CaWO}_{4} \\
\mathrm{MgWO}_{4}\end{array}$ & $\begin{array}{l}410 \text { (Blue) } \\
483 \text { (Blue-white) }\end{array}$ & $\begin{array}{l}\text { Color lamp } \\
\text { High color rendering lamp }\end{array}$ \\
\hline \multicolumn{2}{|c|}{$\begin{array}{l}\mathrm{S}^{2} \text { electron configula- } \\
\text { tion ion }\end{array}$} & $\begin{array}{l}(\mathrm{Ca}, \mathrm{Zn})_{3}\left(\mathrm{PO}_{4}\right)_{2}: \mathrm{Tl} \\
\mathrm{BaSi}_{2} \mathrm{O}_{5}: \mathrm{Pb} \\
\left.3 \mathrm{Ca}_{5}(\mathrm{PO})_{4}\right)_{2} \cdot \mathrm{Ca}(\mathrm{F}, \mathrm{Cl})_{2}: \mathrm{Sb} \\
(\mathrm{Sr}, \mathrm{Mg}, \mathrm{Ba})_{3}\left(\mathrm{PO}_{4}\right)_{2}: \mathrm{Sn}\end{array}$ & $\begin{array}{l}304 \text { (Ultraviolet) } \\
351 \text { (Ultraviolet) } \\
480 \text { (Blue-white) } \\
625 \text { (Orange) }\end{array}$ & $\begin{array}{l}\text { Healthy line lamp } \\
\text { Black light } \\
\text { High color rendering lamp } \\
\text { "' }\end{array}$ \\
\hline \multicolumn{2}{|c|}{ Coactivation } & $\begin{array}{l}3 \mathrm{Ca}_{5}\left(\mathrm{PO}_{4}\right)_{2} \cdot \mathrm{Ca}(\mathrm{F}, \mathrm{Cl})_{2} \\
: \mathrm{Sb}, \mathrm{Mn} \\
3 \mathrm{Sr}_{3}\left(\mathrm{PO}_{4}\right)_{2} \cdot \mathrm{SrF}_{2}: \mathrm{Sb}, \mathrm{Mn}\end{array}$ & $\begin{array}{l}480+580 \text { (White) } \\
490+570 \text { (White) }\end{array}$ & $\begin{array}{l}\text { General illumination lamp } \\
\text { High color rendering lamp }\end{array}$ \\
\hline \multirow[t]{2}{*}{$\mathrm{Mn}$} & Divalent & $\begin{array}{l}\mathrm{MgGa}_{2} \mathrm{O}_{4}: \mathrm{Mn} \\
\mathrm{Zn}_{2} \mathrm{SiO}_{4}: \mathrm{Mn}\end{array}$ & $\begin{array}{l}503 \text { (Blue-green) } \\
525 \text { (Green) }\end{array}$ & $\begin{array}{l}\text { Xerox lamp } \\
\text { High color rendering lamp, } \\
\text { color lamp }\end{array}$ \\
\hline & Tetravarent & $3.5 \mathrm{MgO} \cdot 0.5 \mathrm{MgF}_{2} \mathrm{CeO}_{2}: \mathrm{Mn}^{4+}$ & 657 (Red) & $\begin{array}{l}\text { High color rendering lamp, } \\
\text { color lamp }\end{array}$ \\
\hline & $\mathrm{Fe}$ & $\mathrm{LiAlO}_{2}: \mathrm{Fe}$ & 745 (Far-red) & Agricultural lamp \\
\hline \multirow{2}{*}{$\begin{array}{l}\text { Rare } \\
\text { earth } \\
\text { ion }\end{array}$} & $f-d$ & $\begin{array}{l}\mathrm{Sr}_{2} \mathrm{P}_{2} \mathrm{O}_{7}: \mathrm{Eu}^{2+} \\
3 \mathrm{Sr}_{3}\left(\mathrm{PO}_{4}\right)_{2} \cdot \mathrm{SrCl}_{2}: \mathrm{Eu}^{2+} \\
3 \mathrm{Sr}_{3}\left(\mathrm{PO}_{4}\right)_{2} \cdot \mathrm{CaCl}_{2}: \mathrm{Eu}^{2+} \\
\mathrm{BaMg}_{2} \mathrm{Al}_{16} \mathrm{O}_{27} \\
2 \mathrm{SrO} \cdot 0.84 \mathrm{P}_{2} \mathrm{O}_{5} \cdot 0.16 \mathrm{~B}_{2} \mathrm{O}_{3}: \mathrm{Eu}^{2+}\end{array}$ & $\begin{array}{l}420 \text { (Blue-violet) } \\
450 \text { (Blue) } \\
452 \text { (Blue) } \\
454 \text { (Blue) } \\
480 \text { (Blue-green) }\end{array}$ & $\begin{array}{l}\text { Diazo copying lamp } \\
\text { High color rendering lamp } \\
\text { ", } \\
\text { ", }\end{array}$ \\
\hline & $f-f$ & $\begin{array}{l}\mathrm{Y}_{2} \mathrm{SiO}_{5}: \mathrm{Ce}, \mathrm{Tb} \\
\mathrm{LaPO}_{4}: \mathrm{Ce}, \mathrm{Tb} \\
(\mathrm{Ce}, \mathrm{Tb}) \mathrm{MgAl}_{11} \mathrm{O}_{19} \\
\mathrm{Y}_{2} \mathrm{O}_{3}: \mathrm{Eu} \\
\mathrm{Y}(\mathrm{P}, \mathrm{V}) \mathrm{O}_{4}: \mathrm{Eu}\end{array}$ & $\begin{array}{l}544 \text { (Yellow-green) } \\
544 \text { (Yellow-green) } \\
544 \text { (Yellow-green) } \\
611 \text { (Red) } \\
619 \text { (Red) }\end{array}$ & $\begin{array}{l}\text { High color rendering lamp, } \\
\text { color lamp } \\
\qquad, " \\
\text { ", } \\
\text { High pressure mercury lamp }\end{array}$ \\
\hline
\end{tabular}

Table 4 Typical translucent ceramics

\begin{tabular}{|c|c|c|c|c|c|c|c|c|c|c|c|c|c|}
\hline \multicolumn{3}{|c|}{ Composition } & $\mathrm{Al}_{2} \mathrm{O}_{3}$ & $\mathrm{BeO}$ & $\mathrm{MgO}$ & $\mathrm{CaO}$ & $\mathrm{Y}_{2} \mathrm{O}_{3}$ & $\mathrm{ZrO}_{2}$ & $\mathrm{ThO}_{2}$ & $\mathrm{MgO} \cdot \mathrm{Al}_{2} \mathrm{O}_{3}$ & $\mathrm{CaF}_{2}$ & GaAs & PLZT \\
\hline \multicolumn{3}{|c|}{ Crystal system } & $\begin{array}{l}\text { Hexa- } \\
\text { gonal }\end{array}$ & $\begin{array}{l}\text { Hexa- } \\
\text { gonal }\end{array}$ & Cubic & Cubic & Cubic & Cubic & Cubic & Cubic & Cubic & Cubic & \\
\hline \multicolumn{3}{|c|}{ Melting point $\left({ }^{\circ} \mathrm{C}\right)$} & 2,050 & 2,570 & 2,800 & 2,570 & 2,410 & 2,700 & 3,300 & 2,130 & 1,360 & 1,240 & 1,450 \\
\hline \multirow{3}{*}{$\begin{array}{l}\text { Pro- } \\
\text { cess- } \\
\text { ing }\end{array}$} & \multirow{2}{*}{$\begin{array}{l}\text { Hot } \\
\text { pressing }\end{array}$} & $\left({ }^{\circ} \mathrm{C}\right)$ & 1,500 & 1,200 & 770 & 1,150 & 900 & $1,300 \sim 1,750$ & & & 900 & $900 \sim 1,000$ & $1,000 \sim 1,300$ \\
\hline & & $\left(\mathrm{kg} / \mathrm{cm}^{2}\right)$ & 400 & 2,000 & 100 & 600 & 800 & $500 \sim 30,000$ & & & 2,600 & $600 \sim 3,000$ & $200 \sim 600$ \\
\hline & \multicolumn{2}{|c|}{$\begin{array}{l}\text { High temperature } \\
\text { sintering }\left({ }^{\circ} \mathrm{C}\right)\end{array}$} & 1,950 & 1,800 & 1,750 & & 2,200 & 1,450 & 2,100 & 2,150 & & & \\
\hline
\end{tabular}

instead of a single crystal, is expected.

(d) Infrared reflecting film

Recently, in the field of light source mainly for illumination, power conservation is given a great importance as well. Especially, an efficiency improvement of low pressure sodium lamp or incandescent lamp is attained by reusing a wasted infrared radiation so that it is evaluated in the field of material technology from the point of power conservation realized by using infrared reflecting film.

The production process of infrared reflecting film material and film has been studied in various fields. For light source, a film used in EL, solar cell, optical filter, reflection preventing film and solar system is now applied mostly. As an application to illumination technology, a utilization of semiconductor film in low pressure sodium lamp or a manufacturing of lamp using multilayered interference film of $\mathrm{ZnS}$ and $\mathrm{MgF}_{2}$ as optical filter or cold mirror is already being practiced.

Recently, a lamp, in which an efficiency was improved by feeding back an infrared radiation 
into filament while a multilayered interference film of $\mathrm{SiO}_{2}$ and $\mathrm{TiO}_{2}$ is provided on the surface of halogen lamp, was realized for practical use, wherein a cheaper manufacturing method of lamp by dipping is noticable.

\subsection{Optoelectronics device material}

Optoelectronics is a new field which combines optics and electronics and optoelectronics material is defined as a material which is provided with both features outstandingly.
Refractive index $(\mathrm{N})$ is generally a complex quantity and it is expressed by $\mathrm{N}=\mathrm{n}-\mathrm{jk}$, where $\mathrm{n}$ is so-called refractive index and $\mathrm{k}$ is damping coefficient. Now, $n$ is a coefficient which determines a phase of light and $\mathrm{k}$ is a coefficient which determines a variation in amplitude of light so that $n$ and $k$ are changed by an external effect. This external effect includes electrical field, magnetic field, ultrasonics and light so that it is called as optoelectronics effect.

Figure 1 shows representative optoelectronics

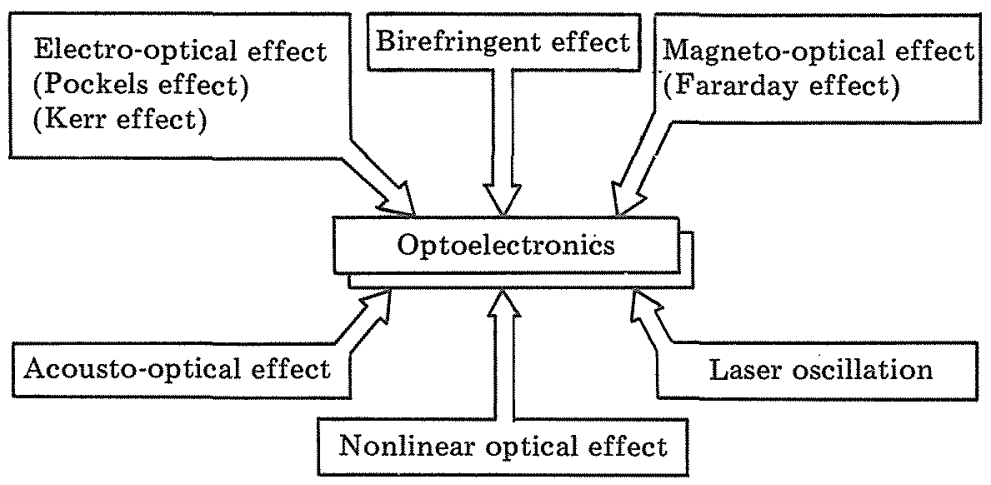

Fig. 1 Type of optoelectronic effect

effects. It is only laser oscillation that is an effect varying $\mathrm{k}$ and others are phenomena varying n. In optoelectronics material, usually a single crystal is used. That is because ion orientation is regular and uniform therein and because it has features such as no scattering, constant crystal orientation and accurate cut-out. Representative optoelectronics material is $\mathrm{LiNbO}_{3}, \mathrm{LiTaO}_{3}$, $\mathrm{Ba}_{2} \mathrm{NaNb}_{5} \mathrm{O}_{15}, \mathrm{KNbO}_{3}, \mathrm{PbMoO}_{4}, \mathrm{TeO}_{2}$ etc.

\section{A Desire for Ceramics from Users}

\subsection{A desire from lamp engineer to material specialist}

A safety and a reliability of lamp greatly depend on a progress of glass and translucent ceramics. Table 5 summarizes performances required from the side of safety and reliability (life) to glass and translucent ceramics for various types of lamp. For glass and light transmissive ceramics, first of all, a property of crack resistance is required. For instance, in metal halide lamp, a chemical reaction of quartz glass with an enclosed material provides a cause of crack or reduces a light flux maintaining ratio. Therefore, a quartz glass not reactive to the enclosed material is desired. Also, in a high pressure sodium lamp, from a similar reason, a translucent ceramics and enclosing glass, which are not reactive to metallic sodium, are desired.

On the other hand, in order to realize a longer life and a higher reliability of lamp, a steady effort of lamp engineer is also required. For example, a mechanism of blackening of glass is not necessarily clear at present even after 50 years since the first practical use of fluorescent lamp. It is the first step for realization of a longer life of fluorescent lamp to make clear the mechanism of blackening of glass by sufficiently utilizing the present material technology.

Furthermore, metal halide lamp is not so popular yet at present even after about 25 years since its first practical use. The reason why the metal halide lamp having an excellent efficiency and color rendering property is not widely used yet is attributable to its shorter life and lower reliability. That is, a crack is produced in quartz 
Table 5 Property of glass and light transmissive ceramics required from safety and reliability

\begin{tabular}{|c|c|c|c|}
\hline \multirow{2}{*}{ Lamp } & \multicolumn{2}{|c|}{ Safety } & \multirow{2}{*}{ Reliability (Life) } \\
\hline & Mechanical & Optical & \\
\hline Bulb & Crack resistant glass & & \\
\hline Halogen bulb & $\begin{array}{l}\text { Crack resistant quartz } \\
\text { glass }\end{array}$ & $\begin{array}{l}\text { UV non-transmissive } \\
\text { cheaper quartz glass }\end{array}$ & \\
\hline Fluorescent lamp & Crack resistant glass & & non-blackening glass \\
\hline $\begin{array}{l}\text { High pressure } \\
\text { mercury lamp }\end{array}$ & $\begin{array}{l}\text { Crack resistant quartz } \\
\text { glass }\end{array}$ & $\begin{array}{l}\text { UV non-transmissive } \\
\text { cheaper quartz glass }\end{array}$ & \\
\hline Metal halide lamp & “ & $"$ & $\begin{array}{l}\text { Quartz glass non-reactive } \\
\text { with enclosed material. } \\
\text { Ne non-transmissive quartz } \\
\text { glass }\end{array}$ \\
\hline $\begin{array}{l}\text { High pressure sodium } \\
\text { lamp }\end{array}$ & Crack resistant ceramics & $\begin{array}{l}\text { UV non-transmissive } \\
\text { ceramics }\end{array}$ & $\begin{array}{l}\text { Glass for enclosing light } \\
\text { transmissive ceramics } \\
\text { non-reactive with } \mathrm{Ne}\end{array}$ \\
\hline
\end{tabular}

glass by a reaction of an enclosed halogenide with quartz glass or a tube wall is blackened by a reaction of an enclosed halogenide with an electrode. It is difficult to analize these chemical reactions because they are carried out in a multicomponent system containg water and impurities or they takes such a long time as several thousand hours. It is an obstacle against a longer life and higher reliability of metal halide lamp that the detail of the above-mentioned chemical reactions is not obvious yet. Its solution by material specialists is being desired by users.

\subsection{A desire to ceramics used as a lamp operating device}

A lamp operating device, also, has a tendency of being small-sized and thinned. A small-sizing and a light-weighting of ballast and transformer have been attained by converting ballast or transformer compried of iron and copper into electron ballast or electron transformer. Also, a starter for starting lamp is changing from bimetal switch or glow switch to semiconductor starter. Dimming or flashing is mostly controlled electronically and the trend of lamp operating device is being directed towards semiconductor device or electronic device. Within this trend, the parts depending on ceramics such as amorphous alloy and ferrite which will replace metallic magnetic material, recently spotlighted high temperature superconductivity ceramics, SIT or SI thyristor, high temperature semiconductor, nonlinear condenser or small-sized laminated condenser will increase more and more expectedly so that a development of these types of material is expectable in a great extent.

\section{Conclusion}

This is only a summary of the Report submitted by the Committee so that the detail shall be preferably referred to the original report. It can not be said that this'survey is completely sufficient. The uncovered subjects will be supplemented in another report on "The Research and Survey of New Material for Light Source" (The Committee started in 1988).

Received November 6, 1989; accepted May 22, 1990 